\title{
Membangun modal sosial pada gabungan kelompok tani
}

\author{
Building social capital for farmer association
}

\author{
Teguh Budi Trisnanto, Fitriani \& Cholid Fatih
}

\author{
Jurusan Ekonomi dan Bisnis Politeknik Negeri Lampung \\ Jalan Soekarno-Hatta No.10, Rajabasa, Rajabasa Raya, Kota Bandar Lampung, Lampung \\ Telepon: (0721) 703995 \\ E-mail:dtetuko@gmail.com; fitriani@polinela.ac.id; cholid_fatih@gmail.com
}

\begin{abstract}
Sumber Makmur farmer's associaton (Gapoktan) have been changed structurally due to village enlargement processes. Differences of opinion, interest conflict, truth and norm, the decreasing the partisipation and cooperation were regarded as threat to Gapoktan performance. This study aims to explore members of Gapoktan's perspective toward social capital values. This article also explores social capital mechanism to realize Gapoktan good performance. This study conducted in Pekon Adiluwih, Adiluwih sub-district, Pringsewu District in 2013. Respondents were Gapoktan management board and members (33 person). Data collected by in-depth interviews. Qualitative description method used to analyze the data. Based on the discussion, the research concludes that: (1) the main social capital elements patch in Sumber Makmur farmer's group are: identity $\left(X_{1}, X_{2}, X_{3}\right)$, vision and goal $\left(X_{4}, X 5\right)$, truth $\left(X_{6}, X_{7}\right)$, smash anxiety $\left(X_{8}, X_{9}\right)$, dan openness $\left(X_{10}\right)$. Positive value of social capital is considered as intrinsic value which create bonds between Gapoktan members. Mechanism to built solidarity of member was developed by strengthen trust to every members, and uniting identity, cooperation, and openness in a synergetic networks.
\end{abstract}

Keywords: social capital, trust, value, norm, networking

\begin{abstract}
Abstrak
Gabungan Kelompok Tani (Gapoktan) Sumber Makmur mengalami perubahan struktural akibat terjadinya pemekaran desa. Perbedaan pandangan, konflik kepentingan, sistem kepercayaan tata nilai dan norma, partisipasi dan kerjasama yang belum kompak menyebabkan belum terbangunnya empati untuk saling membantu yang dapat mengancam soliditas Gapoktan. Penelitian ini bertujuan untuk menelaah tanggapan anggota terhadap nilai-nilai modal sosial yang dimiliki dan merumuskan mekanisme bekerjanya modal sosial dalam mewujudkan soliditas Gapoktan. Penelitian dilakukan di Desa Adiluwih, Kecamatan Adiluwih Kabupaten Pringsewu pada tahun 2013. Responden adalah pengurus dan anggota Gapoktan Sumber Makmur (33 orang). Metode pengumpulan data menggunakan deep interview pada key person. Metode deskriptif kualitatif digunakan untuk analisis data menjawab tujuan yang diajukan. Berdasarkan hasil dan pembahasan disimpulkan bahwa unsur modal sosial utama yang ada pada Gapoktan Sumber Makmur meliputi: identitas $\left(\mathrm{X}_{1}\right.$, $\left.\mathrm{X}_{2}, \mathrm{X}_{3}\right)$, kesamaan visi dan tujuan $\left(\mathrm{X}_{4}, \mathrm{X} 5\right)$, kepercayaan $\left(\mathrm{X}_{6}, \mathrm{X}_{7}\right)$, ketakutan $\left(\mathrm{X}_{8}, \mathrm{X}_{9}\right)$, dan keterbukaan $\left(\mathrm{X}_{10}\right)$. Nilai positif modal sosial ini merupakan nilai intrinsik yang menjadi perekat (bonding) diantara anggota Gapoktan. Mekanisme membangun solidaritas Gapoktan Sumber Makmur dibangun melalui penguatan rasa saling percaya pada segenap unsur (pengurus dan anggota) dan penyatuan kesamaan norma identitas dan nilai kerjasama serta keterbukaan dalam jejaring yang sinergis.
\end{abstract}

Kata kunci: modal sosial, kepercayaan, nilai, norma, jaringan

\section{Pendahuluan}

Subsektor tanaman pangan berkontribusi $10 \%$ terhadap total nilai Output Lampung dengan nilai tambah yang tertinggi $(13,89 \%)$ terhadap PDRB Lampung BPS Lampung (2015). Namun, subsektor tanaman pangan belum optimal merangkai keterkaitan dan memunculkan ketergantungan yang erat dengan subsektor pendukungnya. Penting dilakukan serangkaian upaya untuk meningkatkan kemampuan produktivitas dan nilai tambah melalui tumbuh kembangnya bioindustri perdesaan sebagai subterminal bagi tumbuh kembangnya agroindustri tanaman pangan lokal pada skala yang lebih besar (Fitriani et al. 2014). 
Kecamatan Adiluwih merupakan salah satu dari 8 kecamatan di Kabupaten Pringsewu yang secara intensif mengembangkan pertanian tanaman pangan dan sayuran. Pemanfaatan lahan kering untuk komoditas tanaman pangan dan sayuran sudah berkembang sejak dekade 1970-an (Pemdes Adiluwih 2007). Keberhasilan pembangunan pertanian perdesaan bergantung pada penyelenggaraan usahatani yang efisien. Usaha tani yang efisien mendorong penggunaan faktor-faktor produksi secara optimal dan selanjutnya memberikan keuntungan yang optimal bagi petani (Fitriani \& Zaini 2012); (Fitriani et al. 2010). Keberadaan kelembagaan lembaga pertanian yang produktif penting hadir dalam mensinergikan tercapainya kondisi usahatani yang efisien dan menguntungkan (Fitriani 2015).

Kehadiran kelembagaan pertanian di Desa Adiluwih berkembang seiring dengan laju pertambahan penduduk dan sumber pendapatan masyarakat desa. Pada awal tahun 2012, Desa Adiluwih mengalami perubahan struktur pemerintahan desa. Perubahan struktur ini seiring dengan tuntutan perkembangan struktur ekonomi dan penduduk desa. Desa Adiluwih mengalami pemekaran menjadi tiga desa, yaitu Desa Adiluwih, Desa Srikaton, dan Desa Tunggul Pawenang. Konsekuensi dari perubahan struktur pemerintahan desa tersebut, menyebabkan kelembagaan pertanian yang ada di tingkat desa, yaitu Gapoktan (Gabungan Kelompok Tani) dan kelompok tani juga turut mengalami perubahan. Pada awalnya, Gapoktan yang ada di Desa Adiluwih hanya satu yaitu Gapoktan Sumber Makmur yang meliputi gabungan 24 kelompok tani. Gapoktan Sumber Makmur berdiri pada tahun 2007 dan mendapatkan registerasi dari Departemen Pertanian pada tahun 2008. Pada tahun 2009 Gapoktan Sumber Makmur merupakan salah satu Gapoktan yang melaksanakan program PUAP (Pengembangan Usaha Agribinis Pertanian) dengan prestasi yang baik.

Dengan adanya pemekaran desa, Gapoktan Sumber makmur mengalami perubahan cukup signifikan. Sebagian besar kelompok tani (16 kelompok tani) memisahkan diri menjadi Gapoktan di Desa Srikaton dan Desa Tunggul Pawenang. Begitu pula pengurus yang berdomisili di Desa Srikaton dan Desa Tunggul Pawenang menjadi pengurus Gapoktan di desa baru tersebut. Desa Srikaton terbentuk Gapoktan baru, yaitu Gapoktan Sumber Rejeki. Sementara itu, di Desa Tunggul Pawenang terbentuk Gapoktan Jaya Makmur. Hal ini menyebabkan, struktur kepengurusan Gapoktan dan jumlah kelompok tani yang tergabung di dalam Gapoktan Sumber Makmur menjadi 8 kelompok tani. Perubahan struktural yang sangat signifikan tersebut menimbulkan persoalan internal dalam tata nilai dan aturan lembaga yang tidak sederhana bagi Gapoktan.

Masuknya orang-orang baru dalam sebuah kelembagaan diikuti dengan perubahan aturan main (rule) yang tertuang dalam anggaran dasar dan anggaran rumahtangga, menjadi tantangan baru. Hal baru menyebabkan perubahan. Perubahan akan menuntut penyesuaian-penyesuaian yang sinergis dari setiap elemen yang tergabung dalam sebuah kelembagaan. Perubahan secara struktural tersebut harus mampu disikapi sebagai dinamika kelembagaan. Elemen kekuatan yang harus dimiliki oleh kelompok masyarakat dalam hal ini organisasi tani agar dapat berdaya meliputi: akses komunikasi, percaya diri, kepemimpinan, kelembagaan, kemampuan organisasi, networking, keterampilan, dan terpercaya (Bartle 2008).

Perbedaan pandangan, belum terbangunnya rasa saling percaya, belum menyatunya visi dan misi organisasi, komunikasi yang macet, partisipasi yang minim, kerjasama yang belum kompak, dan belum terbangunnya empathy saling membantu serta munculnya konflik kepentingan, menjadi bibitbibit perpecahan dan terancamnya soliditas kelembagaan Gapoktan. Membangun soliditas kelembagaan akan mewujud melalui tumbuhkembangnya modal sosial yang dimiliki dalam lembaga tersebut. Sebagaimana halnya pada kelembagaan koperasi, prasyarat penting dalam kelangsungan organisasi adalah membangun modal sosial kelompok (Fitriani 2015).

Ide inti dari teori modal sosial sangat sederhana yaitu jaringan peduli sosial. Jaringan memiliki nilai, pertama-tama, bagi orang-orang yang di dalamnya. Secara ekonomi mikro, jaringan memiliki hak pengembalian private (Putnam \& Goss 2002). Menurut Cox (2002) modal sosial memungkinkan anggota masyarakat untuk bertindak secara kolektif dalam memecahkan masalah mereka dan bekerja untuk kebaikan mereka bersama. Jaringan kerjasama sosial memfasilitasi tindakan kolektif. 
Pengertian modal sosial pertama kali dikenalkan oleh Pierre Bourdieu (Syahra 2003) merupakan agregat sumber daya aktual/potensial yang diikat untuk mewujudkan jaringan yang kuat yang dapat merekatkan ketahanan hubungan persahabatan yang saling menguntungkan. Bertolak dari pola pikir tersebut maka Bourdieu mendefinisikan modal sosial sebagai keseluruhan sumberdaya baik yang aktual. maupun potensial yang terkait dengan kepemilikan jaringan hubungan kelembagaan. Putnam (1995) mendefinisikan modal sosial sebagai gambaran organisasi sosial, sebagai jaringan, norma, dan kepercayaan sosial yang memfasilitasi koordinasi dan kerjasama saling menguntungkan.

Modal sosial baru aktif/bekerja bila telah terjadi interaksi dengan orang lain yang dipandu oleh struktur sosial (Yustika 2008). Seperti halnya modal finansial dan modal sumberdaya manusia, modal sosial seperti ini dapat dilihat sebagai sumber yang dapat digunakan baik untuk kegiatan atau proses produksi saat ini, maupun untuk diinvestasikan bagi kegiatan di masa depan.

Gapoktan merupakan kelembagaan pertanian/organisasi yang terbentuk untuk tujuan peningkatan skala usaha dan perbaikan produktivitas masyarakat pertanian (Kementan RI 2013). Adanya interaksi antara orang-orang dalam suatu komunitas Gapoktan dalam mewujudkan tujuan bersama yang ditetapkan menjadi penting dalam kelangsungan sebuah institusi/lembaga. Hasil dari interaksi tersebut akan menciptakan terpeliharanya kepercayaan antar elemen dalam lembaga Gapoktan. Sebuah interaksi dapat terjadi dalam skala individual maupun institusional. Secara individual, interaksi terjadi manakala hubungan dekat antara individu terbentuk satu sama lain yang kemudian melahirkan ikatan emosional. Secara institusional, interaksi dapat lahir pada saat visi dan tujuan satu organisasi memiliki kesamaan dengan visi dan tujuan organisasi lainnya.

Adanya perubahan struktur kelembagaan Gapoktan Sumber Makmur adalah konsekuensi logis tejadinya pemekaran desa menimbulkan perubahan, pergeseran, dan gesekan nilai-nilai antara anggota, dan pengurus. Semangat untuk duduk bersama membangun dan membesarkan Gapoktan sehingga dapat menjadi solusi bagi setiap anggota yang tergabung di dalamnya perlu terus secara sinergis dilakukan bersama. Namun, menurut Nan (2009) modal sosial dalam jaringan organisasi dapat menyulut terjadinya konflik. Ketika jaringan menciptakan batas-batas, termasuk kontrol beberapa tindakan anggota dalam jaringan yang dapat menyebabkan ketidaksetaraan, sehingga memicu konflik. Oleh karena itu, penelitian ini bertujuan untuk menelaah tanggapan anggota Gapoktan terhadap nilai-nilai modal sosial yang dimiliki dan merumuskan mekanisme bekerjanya modal sosial dalam mewujudkan soliditas Gapoktan.

\section{Metode Penelitian}

Penelitian dilakukan di Desa Adiluwih, Kecamatan Adiluwih, Kabupaten Pringsewu. Kegiatan berlangsung pada tahun 2013. Responden adalah pengurus dan anggota Gapoktan Sumber Makmur Sebanyak 33 orang. Anggota Gapoktan adalah kelompok tani sebanyak 8 kelompok. Penelitian merupakan penelitian yang menggunakan metode gabungan kuantitatif dan kualitatif. Metode kuantitatif menggunakan test pengukuran unsur modal sosial. Penelusuran tingkat pemahaman terhadap nilai identitas, kepercayaan dan kesamaan tujuan, kerjasama, akses layanan, dan jejaring lembaga digali menggunakan kuesioner. Selain itu, secara kualitatif dilakukan deep interview pada key person untuk mendapatkan informasi lebih lengkap terkait soliditas kelompok. Metode analisis mulivarate komponen utama digunakan untuk menjawab tujuan yang diajukan.

\section{Hasil dan Pembahasan}

\section{Unsur-unsur modal sosial}

Modal sosial adalah produktif, membuat kemungkinan pencapaian tujuan akhir tertentu yang sulit dicapai. Modal sosial didefinisikan oleh fungsinya dengan dua elemen yang terdiri dari beberapa aspek struktur sosial dan fasilitasi tindakan tertentu dari pelaku yang terlibat di dalamnya. Modal sosial melekat pada struktur hubungan antara pelaku dan antarpelaku (Coleman 1988). Keterlibatan 
norma-norma dan jaringan dalam masyarakat berpengaruh kuat dalam mempengaruhi kinerja kelembagaan (Putnam 1995). Secara kelembagaan, pengelolaan pemerintahan regional lebih efektif di wilayah dengan tingkat kepemilikan modal sosial yang tinggi (Helliwell \& Putnam 1995).

Oleh karenanya, operasionalisasi modal sosial dapat dilihat menurut fungsinya. Pertama, menurut sumber dan pengejawantahannya, secara struktur modal sosial terdiri dari peran dan aturan (roles and rules), jaringan dan hubungan interpersonal dengan pihak lain, serta prosedur dan kejadian (procedurs and precedents). Pada aspek kognisi, terdiri dari norma-norma, nilai-nilai, perilaku, dan keyakinan. Kedua, menurut cakupannya (domains) struktur modal sosial terbentuk dari organisasi sosial dan aspek kognisinya mewujud dalam budaya sipil (civic culture). Ketiga, menurut elemen-elemen umum (common elements) struktur modal sosial terbangun berdasarkan ekspektasi yang mengarah pada perilaku kerjasama yang saling menguntungkan (Yustika 2008).

Unsur-unsur dalam modal sosial tesebut, selanjutnya dituangkan dalam bentuk pertanyaan-pertanyaan terstruktur meliputi: nilai identitas, kepercayaan dan kesamaan tujuan, kerjasama, akses layanan, dan jejaring lembaga. Aspek kognisi dalam modal sosial antara lain: perasaan identitas, perasaan memiliki, sistem kepercayaan, nilai-nilai dan tujuan-tujuan, ketakutan-ketakutan, sikap-sikap terhadap anggota lain dalam masyarakat, persepsi mengenai akses terhadap pelayanan dan bidang-bidang kemasyarakatan lainnya, serta harapan-harapan yang ingin dicapai di masa depan. Daftar pertanyaan pemahaman unsur modal sosial dapat dilihat pada Tabel 1.

Tabel 1.

Daftar pertanyaan pemahaman terhadap unsur modal sosial

\begin{tabular}{|c|c|}
\hline No & Daftar Pertanyaan \\
\hline 1 & Nilai identitas \\
\hline $\mathrm{X} 1$ & Apakah Anda merasa memiliki/Gapoktan ini? \\
\hline $\mathrm{X} 2$ & Apakah Anda aktif dalam keikutsertaan kegiatan Gapoktan? \\
\hline $\mathrm{X} 3$ & Apakah kepentingan Anda terakomodasi (dipenuhi) oleh Gapoktan Anda? \\
\hline 2 & Kesamaan Visi dan Tujuan \\
\hline X4 & Apakah tujuan Anda bergabung di Gapoktan sejalan dengan visi dan tujuan Gapoktan ini? \\
\hline X5 & $\begin{array}{l}\text { Apakah Gapoktan dapat menjadi tumpuan harapan dalam menyelesaikan masalah dalam } \\
\text { usahatani yang anda miliki? }\end{array}$ \\
\hline 3 & Kepercayaan \\
\hline $\mathrm{X} 6$ & Apakah Anda percaya pada pengurus Gapoktan akan bekerja secara bertanggung jawab? \\
\hline $\mathrm{X} 7$ & Apakah Anda yakin pengurus Gapoktan akan memperjuangkan tujuan Gapoktan? \\
\hline 4 & Potensi perpecahan/konflik \\
\hline $\mathrm{X} 8$ & Apakah ada ketakutan timbulnya perpecahan dalam Gapoktan? \\
\hline X9 & Apakah ada ketakutan timbulnya rasa tidak percaya pada pengurus Gapoktan? \\
\hline 5 & Keterbukaan \\
\hline $\mathrm{X} 10$ & $\begin{array}{l}\text { Apakah pengurus Gapoktan terbuka dan transparan dalam pengelolaan program } \\
\text { kegiatan/bantuan? }\end{array}$ \\
\hline $\mathrm{X} 11$ & $\begin{array}{l}\text { Apakah informasi adanya bantuan dari pihak lain bagi Gapoktan disampaikan secara } \\
\text { terbuka kepada anggota lain? }\end{array}$ \\
\hline 6 & Nilai Kebersamaan dan Kerjasama \\
\hline $\mathrm{X} 12$ & Apakah Anda merasakan nilai kebersamaan dalam Gapoktan ini? \\
\hline $\mathrm{X} 13$ & $\begin{array}{l}\text { Apakah Anda sepakat nilai saling membantu/menolong dan kekeluargaa antar anggota } \\
\text { dalam Gapoktan sangat penting? }\end{array}$ \\
\hline $\mathrm{X} 14$ & Apakah pengurus Gapoktan melakukan pertemuan secara teratur? \\
\hline $\mathrm{X} 15$ & Apakah pemilihan pengurus Gapoktan dilakukan secara musyawarah/mufakat? \\
\hline 7 & Pelayanan \\
\hline $\mathrm{X} 16$ & Apakah menurut Anda pengurus Gapoktan telah melayani dengan baik? \\
\hline $\mathrm{X} 17$ & $\begin{array}{l}\text { Apakah tingkat pengetahuan/teknologi budidaya yang Anda miliki meningkat setelah } \\
\text { tergabung dalam Gapoktan? }\end{array}$ \\
\hline $\mathrm{X} 18$ & Apakah Anda merasa puas dengan pelayanan Gapoktan? \\
\hline 8 & Jejaring (networking) \\
\hline $\mathrm{X} 19$ & Apakah Anda pernah diikutsertakan dalam kegiatan pelatihan/SL/program? \\
\hline $\mathrm{X} 20$ & Apakah Anda secara intensif berhubungan dengan petugas Dinas Pertanian/instansi terkait \\
\hline
\end{tabular}


Pada Tabel 1 dapat dilihat bahwa unsur Nilai Identitas diwakili oleh perasaan memiliki kelembagaan Gapoktan oleh seluruh anggotanya. Rasa menjadi bagian dari sebuah organisasi diwujudkan oleh keaktifan anggota dalam keikutsertaan kegiatan Gapoktan dan kepentingannya terakomodasi (dipenuhi) oleh Gapoktan. Unsur Kesamaan Visi dan Tujuan menjadi elemen yang disepakati oleh seluruh anggota Gapoktan. Anggota menilai bahwa visi dan tujuan Gapoktan sejalan dengan tujuan mereka. Hal ini berarti bahwa anggota menempatkan harapan yang tinggi terhadap Gapoktan untuk menjadi bagian dalam penyelesaian masalah dalam usahatani. Sementara itu, pada Nilai Kepercayaan, anggota Gapoktan percaya terhadap pengurus kelompok. Mereka percaya pengurus Gapoktan akan bekerja secara bertanggung jawab dan akan memperjuangkan tujuan Gapoktan. Hal ini menjadi dasar anggota Gapoktan tidak memiliki rasa takut akan potensi timbulnya perpecahan dalam Gapoktan. Unsur keterbukaan ditunjukkan oleh transparansi dalam pengelolaan program kegiatan/bantuan pengurus Gapoktan. Meskipun terdapat 24,25\% (8 anggota) yang menilai bahwa informasi adanya bantuan dari pihak lain bagi Gapoktan belum disampaikan secara terbuka kepada anggota lain.

Pada unsur nilai kebersamaan, anggota Gapoktan menilai bahwa mereka merasakan nilai kebersamaan dalam Gapoktan ini. Anggota sepakat bahwa nilai saling membantu dan kekeluargaan antar anggota dalam Gapoktan sangat penting. Sementara pada nilai Kerjasama, anggota juga menilai bahwa pengurus Gapoktan telah melakukan pertemuan secara teratur. Kerjasama juga tercermin pada saat pemilihan pengurus Gapoktan dilakukan secara musyawarah/mufakat.

Pada aspek pelayanan, anggota menilai bahwa pengurus Gapoktan telah melayani dengan baik. Tingkat pengetahuan/teknologi budidaya yang dimiliki anggota juga meningkat setelah tergabung dalam Gapoktan. Walaupun masih terdapat beberapa anggota yang menilai pelayanan Gapoktan belum memadai $(27,27 \%$ ). Sementara itu, pada aspek jejaring (networking) yang menghubungkan Gapoktan dengan kelembagaan di luarnya (bridging) menunjukkan bahwa, tidak semua anggota terlibat langsung dalam aktivitas tersebut. Baru terdapat 10 anggota $(30,30 \%)$ diantara seluruh anggota Gapoktan yang telah diikutsertakan dalam kegiatan pelatihan/SL/program. Anggota dan pengurus Gapoktan yang secara intensif berhubungan dengan petugas Dinas Pertanian/instansi terkait baru $15,15 \%$ (5 orang).

Namun, untuk hanya menginterpretasikan masing-masing daftar pertanyaan sebagai variabel $\mathrm{X}_{1}, \ldots$, $\mathrm{X}_{120}$ sebenarnya kurang berarti, karena antar variabel tersebut besar kemungkinan saling berkaitan, sehingga diperlukan variabel-variabel baru yang saling tidak berkorelasi. Variabel-variabel baru tsb merupakan kombinasi linear dari variabel-variabel asal. Selanjutnya variabel baru ini disebut komponen utama. Analisis komponen utama ditujukan untuk mereduksi dimensi dari variabel asal, yang semula sebanyak 20 menjadi lebih kecil tanpa harus banyak kehilangan informasi. Banyaknya komponen utama sebagai variabel baru lebih sedikit dari banyaknya variabel asal yang dapat digunakan. Berdasarkan analisis komponen utama menggunakan software Minitab 17 dihasilkan nilai Eigenvalue sebagai indikator besarnya kontribusi masing-masing variabel sebagai pembentuk komponen utama (Tabel 2).

Tabel 2.

Nilai Eigenvalue

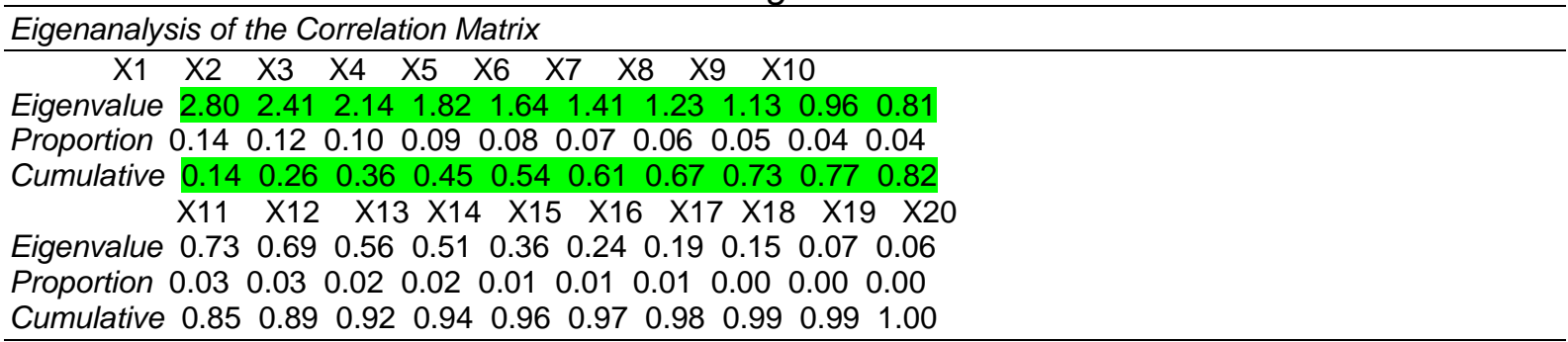

Berdasarkan Tabel 2 dapat dilihat bahwa secara kumulatif komponen utama (KU) $\mathrm{KU}_{1} . . \mathrm{KU}_{10}$ dari pertanyaan $\mathrm{X}_{1} \ldots \mathrm{X}_{10}$ memiliki nilai kumulatif sebesar $82 \%$. Hal ini bearti bahwa pertanyaan $\mathrm{X}_{1} \ldots \mathrm{X}_{10}$ telah mampu menjelaskan $82 \%$ dari keragaman data yang ada. Selanjutnya, dapat dirumuskan bahwa 
unsur modal sosial utama yang ada pada Gapoktan Sumber Makmur meliputi: identitas $\left(\mathrm{X}_{1}, \mathrm{X}_{2}, \mathrm{X}_{3}\right)$, kesamaan visi dan tujuan $\left(X_{4}, X 5\right)$, kepercayaan $\left(X_{6}, X_{7}\right)$, ketakutan $\left(X_{8}, X_{9}\right)$, dan keterbukaan $\left(X_{10}\right)$. Selanjutnya informasi ini penting mendapat perhatian utama dalam upaya mewujudkan soliditas Gapoktan Sumber Makmur. Nilai positif modal sosial ini merupakan nilai intrinsik yang menjadi perekat (bonding) diantara anggota Gapoktan. Modal sosial 'Bonding' penting dalam mendorong pertukaran pengetahuan di kalangan petani (Fisher 2013). Hasil penelitian Willy \& Holm-Muller (2013) menunjukkan bahwa modal sosial memfasilitasi partisipasi dalam inisiatif tindakan kolektif yang kemudian memengaruhi upaya konservasi tanah individu.

Sementara itu, pertanyaan yang mewakili unsur kebersamaan dan kerjasama, pelayanan, dan jejaring $\left(\mathrm{X}_{11 \ldots \ldots . . .} \mathrm{X}_{20}\right)$ berkontribusi sebesar $18 \%$. Kondisi ini menunjukkan bahwa hubungan interaksi unsurunsur Gapoktan perlu perlu ditingkatkan. Ketiga unsur ini merupakan representasi struktur sosial/bridging dalam koordinasi secara vertikal maupun horizontal yang dapat menjadi sumber konflik. Potensi negatif elemen jejaring juga dapat menjadi sumber perpecahan akibat belum mampu mengakomodasi lebih banyak kepentingan anggota. Kondisi ini menurut Nan (2009) terjadi ketika jaringan menciptakan batas-batas, termasuk kontrol beberapa tindakan anggota dalam jaringan yang dapat menyebabkan ketidaksetaraan sehingga memicu konflik. Selain itu, Fisher (2013) menyebutkan bahwa hubungan terlalu dekat juga berpotensi menyebabkan munculnya jaringan eksklusif dan akibatnya dapat berkembang ketidakpercayaan.

\section{Pendekatan modal sosial dalam membangun soliditas Gapoktan}

Menurut van Rijn et al. (2012) modal sosial memiliki tiga dimensi, yaitu modal sosial kognitif, dan dua bentuk modal sosial struktural (bonding dan bridging). Cox (2002) memaparkan tentang kepercayaan dan norma-norma dalam tradisi ekonomi yang dapat berkembang dan memberikan informasi yang menciptakan insentif positif bagi kerjasama. Elemen modal sosial memiliki pengaruh yang besar terhadap pertumbuhan ekonomi melalui beragam mekanisme, seperti meningkatnya rasa tanggungjawab terhadap kepentingan publik, meluasnya partisipasi dalam proses demokrasi, menguatnya keserasian masyarakat dan menurunnya tingkat kekerasan dan kejahatan (Suharto 2008). Deep interview pada tokoh kunci dilakukan untuk tujuan merumuskan mekanisme membangun bekerjanya modal sosial pada Gapoktan. Kunjungan dilakukan ke kediaman pengurus Gapoktan Sumber Makmur dan beberapa pengurus kunci lainnya. Tujuan dari kegiatan ini adalah melihat langsung dan mencari informasi lebih mendalam terhadap kondisi riil yang ada dan persoalan yang dihadapi dalam pengelolaan kelembagaan Gapoktan. Pada periode saat ini Ketua Gapoktan adalah Edi Sugito, Bendahara: Mulyono, dan Sekretaris Aminudin.

Berdasarkan komunikasi intensif dengan tokoh kunci Gapoktan Sumber Makmur, maka diskusi mengenai mekanisme bekerjanya modal sosial dalam mewujudnya soliditas Gapoktan dirumuskan. Selanjutnya, mekanisme bekerjanya modal sosial dalam menyelesaikan persoalan kelembagaan pada Gapoktan dapat dilihat pada Gambar 1.

Pemecahan persoalan soliditas kelembagaan melalui penguatan modal sosial menjadi kunci berlangsungnya sinergi dalam sebuah organisasi. Maju dan berkembangnya Gapoktan akan bergantung dari soliditas anggota dan pengurus untuk melangkah bersama mencapai tujuan bersama yang telah ditetapkan. Lembaga yang menyatu dalam visi dan misi. Apabila petani bersatu dalam wadah lembaga pertanian, selain lebih mandiri dan otonom dalam mengatasi persoalannya juga tentunya akan memungkinkan untuk pengembangan organisasi di masa yang akan datang. Dengan kepaduan segenap unsur dalam kelembagan, petani akan dapat keluar mengatasi persoalan produksi, permodalan, organisasi, maupun pemasaran. Berdaya secara berkelompok dalam wadah kelembagaan pertanian, akan memberikan kemudahan dalam mengembangkan komoditas unggulan daerah yang sangat penting artinya bagi keberlangsungan proses usahatani dan perekonomian perdesaan. 


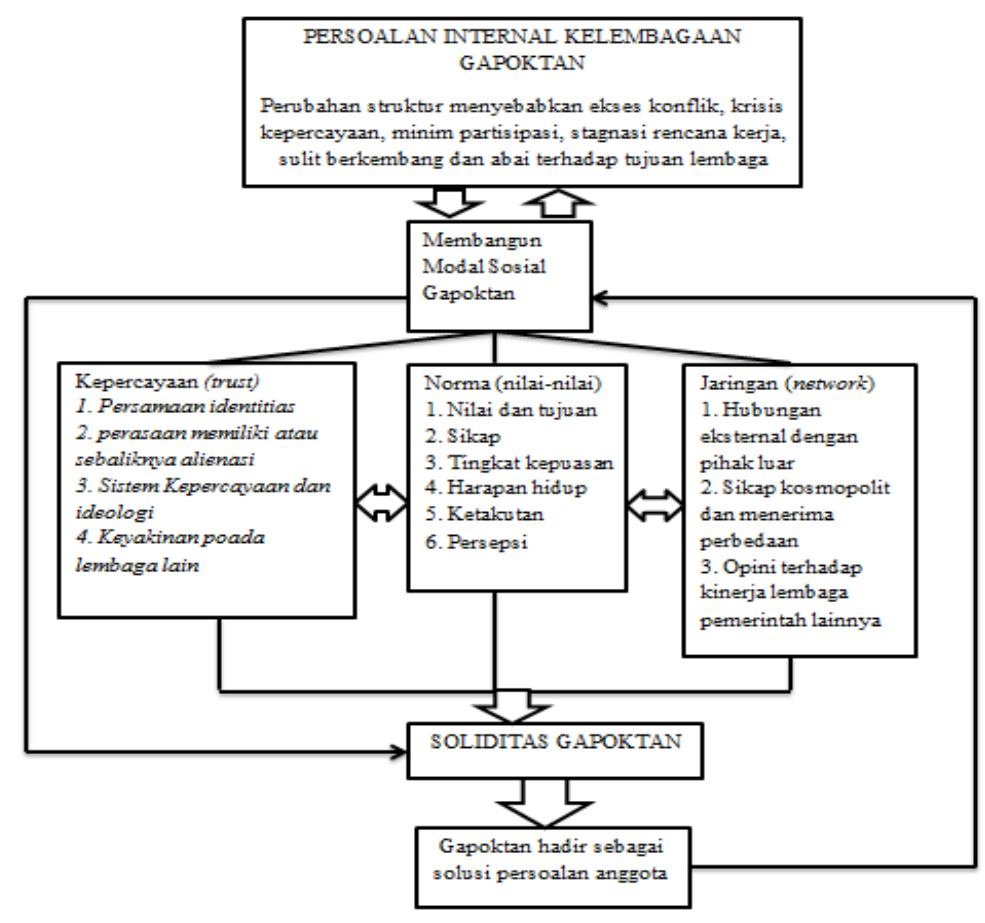

Gambar 1.

Mekanisme modal sosial mewujudkan soliditas Gapoktan

Soliditas lembaga Gapoktan yang terbangun oleh modal sosial merupakan rintisan usaha dari, oleh dan untuk setiap elemen yang ada di dalam Gapoktan itu sendiri. Modal sosial menyebabkan terciptanya bonding (ikatan/link) antar element dalam kelembagaan. Kelembagaan Gapoktan yang solid akan mampu memberikan layanan dan fungsi optimal dalam menyediakan akses produksi, keuangan, pemasaran, dan perkembangan teknologi kepada anggotanya.

Soliditas kelembagaan yang tercermin dari kepercayaan, kerjasama yang semakin baik, dan jaringan kerja yang lebih efektif, memungkinkan fungsi dan peran lembaga dapat berjalan optimal. Pengelolaan Gapoktan akan berhasil dilihat dari dampaknya terhadap penguatan modal petani, peningkatan produktivitas, peningkatan kapasitas produksi, kemampuan dan daya tawar dengan lembaga pasar lain, sehingga memberikan sumbangan bagi peningkatan pendapatan anggotanya.

Menurut Nan (2009) pada tata kelola jaringan jaringan inklusif, kepercayaan dan hubungan timbal balik seperti berbagi pengetahuan adalah aliran utama dipertukarkan melalui jaringan. Jaringan inklusif lebih adaptif terhadap resolusi konflik yang konstruktif, bagaimana kita dapat mendukung pengembangan lebih lanjut dari jaringan inklusif seperti itu? Perubahan sosial yang lebih luas diperlukan untuk memungkinkan jaringan yang lebih inklusif. Jaringan inklusif yang dibangun pada hubungan timbal balik, kepercayaan, dan norma-norma cukup fleksibel untuk merangkul keragaman jaringan. Kita perlu membangun hubungan timbal balik, kepercayaan, dan norma-norma yang fleksibel.

Ruseva et al. (2016) dalam studinya menyimpulkan bahwa keragaman kemitraan organisasi, kerjasama, dan nilai-nilai bersama antara anggota, serta kepercayaan berhubungan dengan tingkat keberhasilan yang lebih tinggi. Kapasitas organisasi, kepercayaan, kesukarelaan, dan dukungan keuangan juga menjadi faktor penting yang mempengaruhi persepsi keberhasilan. Kerangka teori modal sosial dapat berkontribusi untuk menjelaskan mengapa banyak dari kelembagaan pertanian yang terorganisasi secara tradisional, besar dan kompleks telah gagal selama beberapa dekade terakhir (Nilsson et al. 2012). Strategi pengembangan melalui integrasi vertikal dan integrasi horizontal telah menciptakan jurang antara anggota dan lembaga yang menaunginya. 
Hal ini telah menyebabkan berkurangnya saling percaya dan kurang interaksi tatap muka diantara anggota, serta antara anggota dan pengurus. Lebih lanjut menyiratkan kurangnya keterlibatan antara anggota dan kurangnya kebanggaan terhadap kelembagaannya (koperasi), sehingga menimbulkan kesulitan dalam memecahkan masalah tindakan kolektif. Oleh karena itu, nilai yang terkandung dalam modal sosial memiliki dampak serius pada kinerja ekonomi kelembagaan.

Fisher (2013) menjelaskan bahwa hubungan modal sosial antara petani dan pemerintah yang ditemukan menunjukkan tingkatan yang rendah. Hal ini disebabkan oleh tingginya tingkat ketidakpercayaan dan kurangnya kepercayaan diri dalam informasi yang diberikan. Hubungan tingkat tinggi dapat 'menjembatani' modal sosial antara petani dan dokter hewan misalnya dapat terjadi dalam jangka panjang karena kontak teratur dan konsisten, terkait dengan tingkat kepercayaan yang tinggi dan transfer pengetahuan.

Onyx \& Bullen (2000) menyatakan bahwa modal sosial pada umumnya lebih tinggi di pedesaan dibandingkan dengan daerah perkotaan, terutama dalam kaitannya dengan Faktor A (Partisipasi dalam Masyarakat Lokal), Faktor C (Perasaan Trust dan Keamanan), dan Faktor D (Koneksi Neighborhood). Di sisi lain, wilayah metropolitan, dan khususnya dalam kota, dinilai lebih tinggi pada Faktor B (Dinas Sosial, atau proaktif dalam Konteks Sosial) dan Faktor F (Toleransi Diversity). Pola ini tampaknya menunjukkan bahwa masyarakat pedesaan menghasilkan ikatan modal sosial yang cukup besar, ditandai dengan saling mendukung kuat dalam tingkat lokal dan tingkat partisipasi yang tinggi dalam kehidupan masyarakat. Namun, dukungan tersebut kemungkinan akan terbatas pada orang dalam dan tidak dapat diperpanjang untuk kelompok minoritas dalam area lokal atau yang berada di luar daerah. Pada sisi lain, daerah perkotaan dapat dicirikan oleh toleransi yang lebih besar dan inisiatif individu dalam lingkungan sosial, menunjukkan ikatan lemah, atau modal sosial yang menjembatani. Hasil penelitian senada juga dilakukan oleh Compton et al. (2011); (Helliwell \& Putnam 1995).

\section{Simpulan}

Unsur modal sosial utama yang ada pada Gapoktan Sumber Makmur meliputi: identitas $\left(\mathrm{X}_{1}, \mathrm{X}_{2}, \mathrm{X}_{3}\right)$, kesamaan visi dan tujuan $\left(X_{4}, X 5\right)$, kepercayaan $\left(X_{6}, X_{7}\right)$, ketakutan $\left(X_{8}, X_{9}\right)$, dan keterbukaan $\left(X_{10}\right)$. Selanjutnya informasi ini penting mendapat perhatian utama dalam upaya mewujudkan soliditas Gapoktan Sumber Makmur. Nilai positif modal sosial ini merupakan nilai intrinsik yang menjadi perekat (bonding) diantara anggota Gapoktan. Unsur kebersamaan dan kerjasama, pelayanan, dan jejaring $\left(\mathrm{X}_{\left.11 \ldots \ldots . . \mathrm{X}_{20}\right)}\right)$ berkontribusi sebesar $18 \%$. Kondisi ini menunjukkan bahwa hubungan interaksi unsur kebersamaan dan kerjasama, pelayanan dan jejaring antar anggota dan anggota dengan pengurus serta diantara pengurus Gapoktan perlu diperbaiki kembali. Ketiga unsur ini merupakan representasi struktur sosial/bridging dalam koordinasi secara vertikal maupun horizontal yang dapat menjadi sumber konflik. Potensi negatif elemen jejaring juga dapat menjadi sumber perpecahan akibat belum mampu mengakomodasi lebih banyak kepentingan anggota. Mekanisme membangun Soliditas Gapoktan Sumber Makmur dibangun melalui penguatan rasa saling percaya pada segenap unsur (pengurus dan anggota) dan penyatuan kesamaan norma identitas dan nilai kerjasama serta keterbukaan dalam jejaring yang sinergis.

\section{Daftar Pustaka}

Barney JB \& Ouchi WG (1986) Organizational Economic. San Fransisco: Jossey-Bass Publisher

Bartle P (2008) Element of Community Strength. [Diakses pada 21 Mei 2016] http://www.scn.org/mpfc/modules/mea-elin.htm.

Coleman JS (1988) Social capital in the creation of human capital. The American Journal of Sociology 94:95-120.

Compton E \& Beeton RJS (2011) An accidental outcome: Social capital and its implications for Landcare and the "status quo". Journal of Rural Studies 28:149-160. 
Cox E (2002) Australia: Making the Lucky Country. In: Putnam RD (ed) Democracies in Flux: The Evolution of Social Capital in Contemporary Society. Oxford: Oxford University Press, Inc.:395-412.

Fisher R (2013) 'A gentleman's handshake': The role of social capital and trust in transforming information into usable knowledge. Journal of Rural Studies 31:13-22.

Fitriani (2015) Penguatan kapasitas kelembagaan gapoktan melalui pembentukan koperasi pertanian.. Jurnal Masyarakat, Kebudayaan dan Politik 28(2):63-69.

Fitriani, Arifin B \& Ismono H (2010) Analisis skala ekonomi produksi tebu di propinsi lampung. PANGAN 19(4):303-315.

Fitriani, Sutarni, Ismono H \& Haryono D (2014) Kinerja Sub Sektor Tanaman Pangan pada Sektor Pertanian Lampung. In JHMS Muslimin, TAD Nugroho, GWF Rohmah, LFLPH Perwitasari (Eds). Prosiding Seminar Nasional Kedaulatan Pangan dan Pertanian. Yogyakarta: Jurusan Sosial Ekonomi Pertanian Faperta UGM. 212-220.

Fitriani \& Zaini M (2012) Efficiency of economics of catfish growing business. Jurnal Ilmiah ESAI $6(2)$.

Helliwell JF \& Putnam RD (1995) Economic growth and social capital in Italy. Eastern Economic Journal 21(3).

Kementan RI. Permentan No. 82 tahun 2013 (2013).

Nan SA (2009) Social Capital in Exclusive and Inclusive Networks: Satisfying Human Needs through Conflict and Conflict Resolution. In: Cox M (ed) Social Capital and Peace Building Creating and Resolving Conflict with Trust and Social Networks. London: Routledge.

Nilsson J, Svendsen GLH \& Svendsen GT (2012) Are large and complex agricultural cooperatives losing their social capital? Journal Agribusiness 28 (2):187-204.

Onyx J \& Bullen P (2000) Measuring social capital in five communities. The Journal of Applied Behavioral Science 36(1):3-42.

Pemerintahan Desa Adiluwih Kecamatan Adiluwih Kabupaten Pringsewu (2009) Monografi Desa. Adiluwih.

Putnam RD \& Goss KA (eds) (2002) Democracies in Flux: The Evolution of Social Capital in Contemporary Society. Oxford University Press, Inc.

Putnam RD (1995) Bowling alone. Journal of Democracy:65-78.

Ruseva TB, Farmer JR, \& Chancellor C (2016) Networking for conservation: social capital and perceptions of organizational success among land trust boards. Journal Ecology and Society 21(2):50.

Stone W (2001) Measuring Social Capital: Towards a Theotetically Informed Measurement Framework for Researching Social Capital in Family and Community Life. Melbourne: Australian Institute of Family Studies-Commonwealth of Australia.

Suharto E (2008) Pendampingan Sosial Dalam Pemberdayaan Masyarakat Miskin: Konsespsi dan $\begin{array}{lllll}\text { Strategi. } & \text { [Diakses } & \text { pada } & 26 & \text { Maret }\end{array}$ http:www.policy.hu/suharto/modul_a/makindo_32.htm.

Syahra R (2003) Modal sosial: konsep dan aplikasi. Perkembangan konsep modal sosial. Jurnal Masyarakat Dan Budaya 5(1):1-22.

van Rijn F, Bulte E, \& Adekunle A (2012) Social capital and agricultural innovation in Sub-Saharan Africa. Journal of Agricultural Systems 108:112-122.

Willy DK \& Holm-Müller K (2013) Social influence and collective action effects on farm level soil conservation effort in rural Kenya. Journal Ecological Economics 90:94-103.

Yustika AE (2008) Ekonomi Kelembagaan: Definisi, Teori dan Strategi. Malang: Bayumedia. 